\title{
Factors associated with the iron nutritional status of Brazilian children aged 4 to 7 years
}

\author{
Fatores associados ao estado nutricional \\ de ferro em crianças brasileiras \\ de 4 a 7 anos
}

Hercílio Paulino ANDRÉ ${ }^{1}$

Sarah Aparecida VIEIRA ${ }^{1}$

Sylvia do Carmo Castro FRANCESCHINI ${ }^{1}$

Andréia Queiroz RIBEIRO ${ }^{1}$

Helen Hermana Miranda HERMSDORFF ${ }^{1}$

Silvia Eloiza PRIORE ${ }^{1}$

\section{A B S T R A C T}

\section{Objective}

To evaluate factors associated with the iron nutritional status of Brazilian children aged 4 to 7 years in the city of Viçosa, Minas Gerais state, Brazil.

\section{Methods}

This is a cross-sectional study of 357 children aged 4-7 years who had been followed-up up for during their first six months of life by the Breastfeeding Support Program. Socioeconomic and demographic characteristics, feeding practices, nutritional status (height-for-age and body mass index-for-age), and serum ferritin and hemoglobin concentrations were evaluated. Multiple linear regression analysis was carried out to evaluate factors independently associated with iron nutritional status (hemoglobin and ferritin), considering $\alpha=0.05$ as the significance level.

\section{Results}

The prevalence of anemia and iron deficiency was (34) $9.52 \%$ and (11) $11.00 \%$, respectively. The factors independently associated with anemia were younger child age, low maternal education, low height-for-age Z-scores, and children of single and separated mothers or widows. Iron deficiency was associated with child younger age and consumption of chocolates and chocolate flavored milk.

\footnotetext{
1 Universidade Federal de Viçosa, Departamento de Nutrição e Saúde, Programa de Pós-Graduação em Ciência da Nutrição. Campus Universitário, Av. Peter Henry Rolfs, s/n., 36570-000, Viçosa, MG, Brasil. Correspondência para/Correspondence to: SE PRIORE. E-mail: <sepriore@gmail.com>.
} 


\section{Conclusion}

The results obtained allow us to conclude that anemia among children 4-7 years of age is a public health problem in the city of Viçosa, Minas Gerais. Therefore, there is a need for intervention measures targeting children in this age group. These measures can be implemented through food and nutritional education by encouraging the consumption of iron-rich foods.

Keywords: Anemia. Child. Iron deficiency. Iron-deficiency anemia.

\section{RE S U M O}

\section{Objetivo}

Avaliar fatores associados ao estado nutricional de ferro em crianças brasileiras de 4 a 7 anos de idade, no município de Viçosa, Minas Gerais.

\section{Métodos}

Trata-se de um estudo transversal com 357 crianças que foram acompanhadas nos primeiros seis meses de vida, pelo Programa de Apoio à Lactação. Obteve-se informações referentes as condições socioeconômicas, demográficas, práticas alimentares, estado nutricional (estaturalidade e índice de massa corporal/idade), concentrações de ferritina e de hemoglobina. Realizou-se análise de regressão linear múltipla para avaliar os fatores independentemente associados ao estado nutricional de ferro (hemoglobina e ferritina) considerando-se o nivel de significância de $\alpha=0,05$.

\section{Resultados}

As prevalências de anemia e deficiência de ferro foram de (34) 9,52\% e (11) 11,00\% respectivamente. Os fatores independentemente associados a anemia foram menor idade da criança, menor escolaridade da mãe, baixa estatura para idade em escore-Z, e ser filho de mães solteiras, separadas ou viúvas. A deficiência de ferro foi associada a menor idade da criança e consumo de chocolates/achocolatados.

\section{Conclusão}

Os resultados do presente estudo permitem concluir que no município de Viçosa, a anemia apresenta-se como um problema de saúde pública ligeiro em crianças de 4 a 7 anos de idade. Diante desse problema, verifica-se a necessidade de medidas de intervenção voltadas para o grupo infantil. Essas medidas podem ser feitas com a educação alimentar e nutricional, estimulando o consumo dos alimentos fontes de ferro.

Palavras-chave: Anemia. Crianças. Deficiência de ferro. Anemia ferropriva.

\section{INTRODUCTION}

Anemia is the condition in which the blood hemoglobin concentration is below normal values for age, gender, physiological status, and altitude [1]. It can result from an inflammation, infection, or nutritional deficiencies, such as insufficient dietary intake of vitamin $A$, vitamin $\mathrm{B}_{12}$, iron, and folic acid [2].

Iron deficiency is the main cause of nutritional anemia. It affects the immune system and impairs children growth and development, affecting both developing and developed countries, with high prevalence in children and pregnant women [3].
One of the factors associated with the iron nutritional status of children is the high iron requirements due to their rapid growth and the insufficient consumption of foods that are good sources of iron, such as beef, liver, chicken, fish, and dark green leafy vegetables [4]. The consumption of cow milk and goat milk before the first six months of life is another risk factor for iron deficiency due to their low level of this nutrient; in addition, they can cause gastrointestinal bleeding inducing fecal blood loss [5].

It is estimated that anemia affects 1,620 billion people around the world, and the prevalence of iron deficiency is 2.5 times higher 
than that of anemia [2]. In Brazil, according to data provided by the Pesquisa Nacional de Demografia e Saúde da Criança e da Mulher [6] (National Demographic and Health Survey of Children and Women), anemia affects $20.9 \%$ of children below 5 years of age, and the highest percentages were observed in the Southeastern and Northeastern regions of the country, with approximately $22.6 \%$ and $25.5 \%$, respectively.

Anemia and iron deficiency are associated with serious cognitive and motor development impairment and poor school performance in children, and are thus considered as public health problems. Their consequences affect not only population health but also the social and economic development of the world [7].

Therefore, the objective of this study was to evaluate factors associated with the iron nutritional status of Brazilian children aged 4-7 years in the city of Viçosa, Minas Gerais.

\section{METHODS}

This is a cross-sectional study of 357 children aged 4-7 years who had been followedup up for during their first six months of life by Programa de Apoio a Lactação (PROLAC, Breastfeeding Support Program).

Programa de Apoio a Lactação is an Extension Program of the Universidade Federal de Viçosa in partnership with the São Sebastião Hospital and the Breast Milk Bank of the city of Viçosa. This program is aimed at carrying out activities and providing guidance to the mothers during the postpartum period to ensure the promotion of breastfeeding and nutritional care to lactating mothers and infants in the first six months of life.

The present study was carried out in Viçosa, a city located in the microregion of Zona da Mata in the state of Minas Gerais. Viçosa's territorial area is $299.418 \mathrm{~km}^{2}$, and its population is approximately 72,220 inhabitants [8].

Data were collected from 357 children, and the sample was selected using simple random sampling, the easiest form of probability sampling. Hemoglobin concentration was evaluated in the sample of 357 children and serum ferritin in a sub-sample of 100 children.

The inclusion criteria were: children whose health status had no changes that could affect their nutritional status and biochemical evaluation; children with birth records of birth weight and length; children who had medical records that included contact and location information.

The present study was approved by the Ethics Committee for research on humans of the Universidade Federal de Viçosa ( $n^{\circ} 892.476$ on 9/12/2014). The parents or guardians responsible for the children were informed about the objectives and procedures of the study, and those who agreed to participate signed an Informed Consent Form.

The iron nutritional status was evaluated by determining hemoglobin $(\mathrm{N}=357)$ and serum ferritin $(n=100)$ concentrations. Blood was collected $(8 \mathrm{~mL})$ after 8 hours fast, and the hemoglobin and serum ferritin concentrations were determined using an electronic counter at the Division of Health of the Universidade Federal de Viçosa. Hemoglobin cut-off points for diagnosing anemia were 11 and $11.5 \mathrm{~g} / \mathrm{dL}$ for children below and $\geq 60$ months of age, respectively [9]. Serum ferritin levels were used to detect iron deficiency, and the cut-off points were $12 \mu \mathrm{g} / \mathrm{L}$ and $15 \mu \mathrm{g} / \mathrm{L}$ for children below and $\geq 60$ months of age, respectively [1].

In the sub-sample of 100 children, serum levels of high-sensitivity C-Reactive Protein (hs-CRP) were determined using the latex particle enhanced immunoturbidimetric assay. The presence of infection was not detected, i.e., hs-CRP levels were $<10 \mathrm{mg} / \mathrm{L}[10]$.

The anthropometric assessment (weight and height) was carried out at the Division of Health of the Universidade Federal de Viçosa. Height-for-Age (H/A) and Body Mass Index-for Age (BMI/A) Z-scores were calculated using 
WHO Anthro Plus software (World Health Organization, Geneva, Switzerland) [11]. Deviations from the desirable range of nutritional status were detected according to the cut-off points recommended by the $\mathrm{WHO}$ and adopted by the Ministry of Health [12].

Dietary intake assessment was carried out during the follow-up visit, which was scheduled to occur within one week of blood collection at the Division of Health of the Universidade Federal de Viçosa. During the same visit, a food frequency questionnaire was administered for a qualitative identification of iron-rich foods (beef, pork, chicken, fish, liver, dark green leafy vegetables, and beans), foods that can enhance iron absorption (fruits and natural fruit juices), and foods that can inhibit iron absorption (coffee, black tea, chocolate flavored milk, soft drinks, and chocolate). Some dietary practice characteristics were evaluated: consumption of milk, fruit, or fruit juice before, during, or shortly after salty foods, exclusive breastfeeding, and the age of introduction of complementary foods.

Data were entered twice into the Microsoft Office Excel 2010. Data analysis was carried using the Statistical Package for Social Science (SPSS Inc., Chicago, Illinois, United States) for Windows, version 21.0 and Stata software (Stata Corporation, College Station, Texas, United States), version 13.0. The outcomes in the sample were analyzed by frequency distribution (qualitative variables) and measures of central tendency and variability (quantitative variables). The ShapiroWilk test was used to establish if the variables were normally distributed.

The Mann-Whitney test (non-parametric) and the Student's t-test (parametric) were used to compare two independent groups. Oneway Analysis of Variance (ANOVA) and the Kruskall-Wallis test (not parametric) were used to compare three independent groups. Pearson correlation test was used to evaluate the correlation between quantitative, continuous variables that were normally distributed; and the Spearman's Correlation was used for at least one variable that was not normally distributed. For all statistical tests, $\alpha=0.05$ was considered the significance level.

Multiple linear regression analysis was carried out to evaluate the association between the variables of interest and hemoglobin and serum ferritin concentrations. The criterion for inclusion of variables in the multiple linear regression was their association with the outcome (dependent variable) in the simple linear regression analysis, with $p$-value less than or equal to 0.20 . The assumptions of normality, linearity, and homoscedasticity of variance were verified to evaluate the adequacy and fitness of the linear regression model.

The dependent variable serum ferritin concentration was not normally distributed; therefore, square root transformation was applied to include this variable in the linear regression analysis, considering $\alpha=0.05$ as the significance level.

\section{RE S U L T S}

The total sample of the study was composed of 357 children with mean age (Standard DeviationSD) $71.54(11.75 \%)$ months, of whom 190 $(53.22 \%)$ were males. The children in the subsample of 100 had a mean age (SD) of 71.73 (9.71\%) months, of whom 48 (48.00\%) were males.

Of the 357 children evaluated, 34 (9.52\%) had anemia, mean value $(12.56 \mathrm{~g} / \mathrm{dL})$, SD $(0.82)$ and the minimum hemoglobin concentration was $9.8 \mathrm{~g} / \mathrm{dL}$. Of the 100 children in the sub-sample $11(11.00 \%)$ had iron deficiency, mean value $(29.12 \mu \mathrm{g} / \mathrm{L}), \mathrm{SD}(14.16 \%)$ and the minimum serum ferritin concentration was $3.1 \mu \mathrm{g} / \mathrm{L}$.

Ninety-seven percent of the children in the total sample had adequate height-for-age, and $3.00 \%$ had low-height-for-age; $72.83 \%$ were eutrophic, $2.52 \%$ were too thin, and $24.65 \%$ were at risk of being overweight and obese. 
In the sub-sample of 100 children, $97.5 \%$ had adequate height-for-age and $2.50 \%$ had low-height-for-age; $76.00 \%$ were eutrophic, $2,0 \%$ were too thin, and $22.00 \%$ were at risk of being overweight and obese.

As for the hemoglobin and serum ferritin concentrations, males had lower serum ferritin concentrations than females $(p=0.01)$, and the children of single or separated mothers had lower hemoglobin concentrations than the children of married mothers or mothers who had a domestic partner $(p<0.001)$ (Table 1).

With regard to household income, the children from households with per capita income less than or equal to $1 / 4$ of the minimum wage had lower hemoglobin concentrations $(p=0.04)$ (Table 1).

As for food intake, it was observed that the children who consumed legumes (beans) and dark green leafy vegetables had higher levels of serum ferritin than the those who did not consume these foods ( $p=0.02$ and $p=0.04$, respectively). With regard to milk and other dairy products (yogurt, cheese, and requeijão (a loose, ricotta-like cheese), children who consumed these foods had lower serum ferritin values ( $p=0.02$ ) (Table 2).

Children who consumed milk before, during, or shortly after meals had lower ferritin levels when compared to children who did consume these foods $(p<0.05)$. As for their family history, the children whose mothers had anemia during pregnancy had lower ferritin levels $(p<0.05)$.

Significant positive correlations were observed between hemoglobin concentration and the child current weight, height-for-age Z-scores, child age, and maternal age. Serum ferritin had a positive and significant correlation with the child current weight and maternal age (Table 3).

In the final multiple linear regression model, the following variables remained independently associated with hemoglobin concentration: child age, maternal education, height-for-age Z-scores, and maternal marital status. Regression analysis showed that one month increase in the child age, one unit increase in height-forage Z-score, and one year increase in maternal education resulted in an increase in hemoglobin levels by $0.01 \mathrm{~g} / \mathrm{dL}(<0.001), 0.09 \mathrm{~g} / \mathrm{dL}(p=0.02)$, and $0.03 \mathrm{~g} / \mathrm{dL}$, respectively. Maternal marital status as single or widow reduced child's hemoglobin levels by $0.32 \mathrm{~g} / \mathrm{dL}(p<0.001)$ (Table 4$)$.

With regard to serum ferritin levels, the consumption of chocolates or chocolate flavored milk and child age remained associated with serum ferritin concentration in the final multiple linear regression model. It was observed that one month increase in the child age resulted in an increase in the serum ferritin concentration by $0.04 \mu \mathrm{g} / \mathrm{L}(p<0.001)$, and the weekly consumption of chocolates or chocolate flavored milk resulted in a reduction in the serum ferritin concentration by $2.32 \mu \mathrm{g} / \mathrm{L}(p<0.001)$ (Table 4$)$.

\section{DISCUSSION}

The prevalence of anemia found in the present study was $9.52 \%$, and it was considered to be a public health problem according to the World Health Organization (WHO) classification [1]. In another research [13] addressing the prevalence of anemia and associated factors in children aged 6 to 24 months attending public schools in the city Venâncio Aires, Rio Grande do Sul, Brazil, prevalence of anemia was found to be approximately $11.5 \%$.

The prevalence of iron deficiency among 12-24 month-old New Zealand children was $23.3 \%$, characterized by the decreased iron stores [10]. In a study with 12-month-old European children, iron deficiency was $15.6 \%$ [14]. In the present study, prevalence of iron deficiency was found to be $11.0 \%$.

These findings indicate that the prevalence of anemia and iron deficiency in other regions of Brazil and around the world varies widely. 


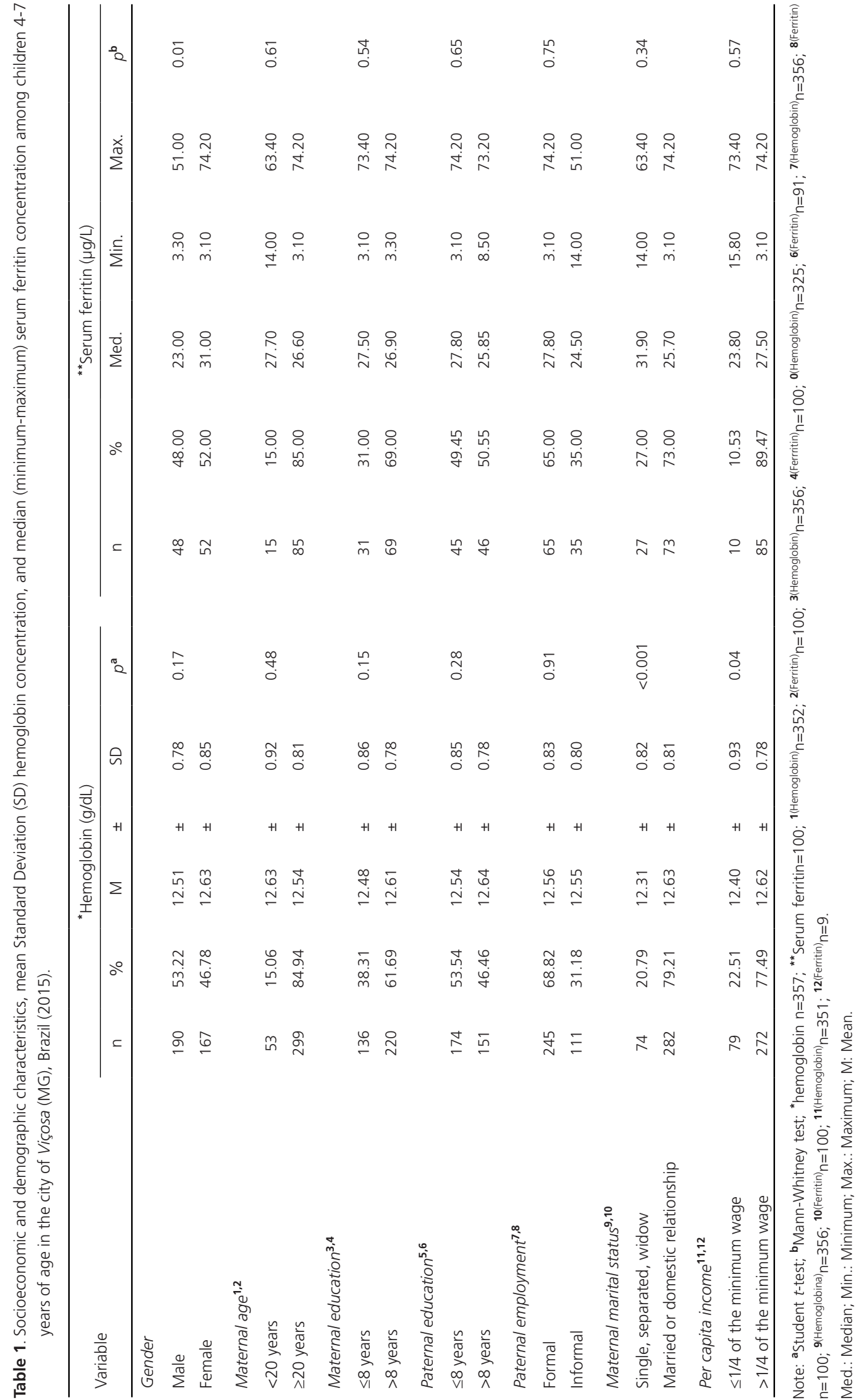




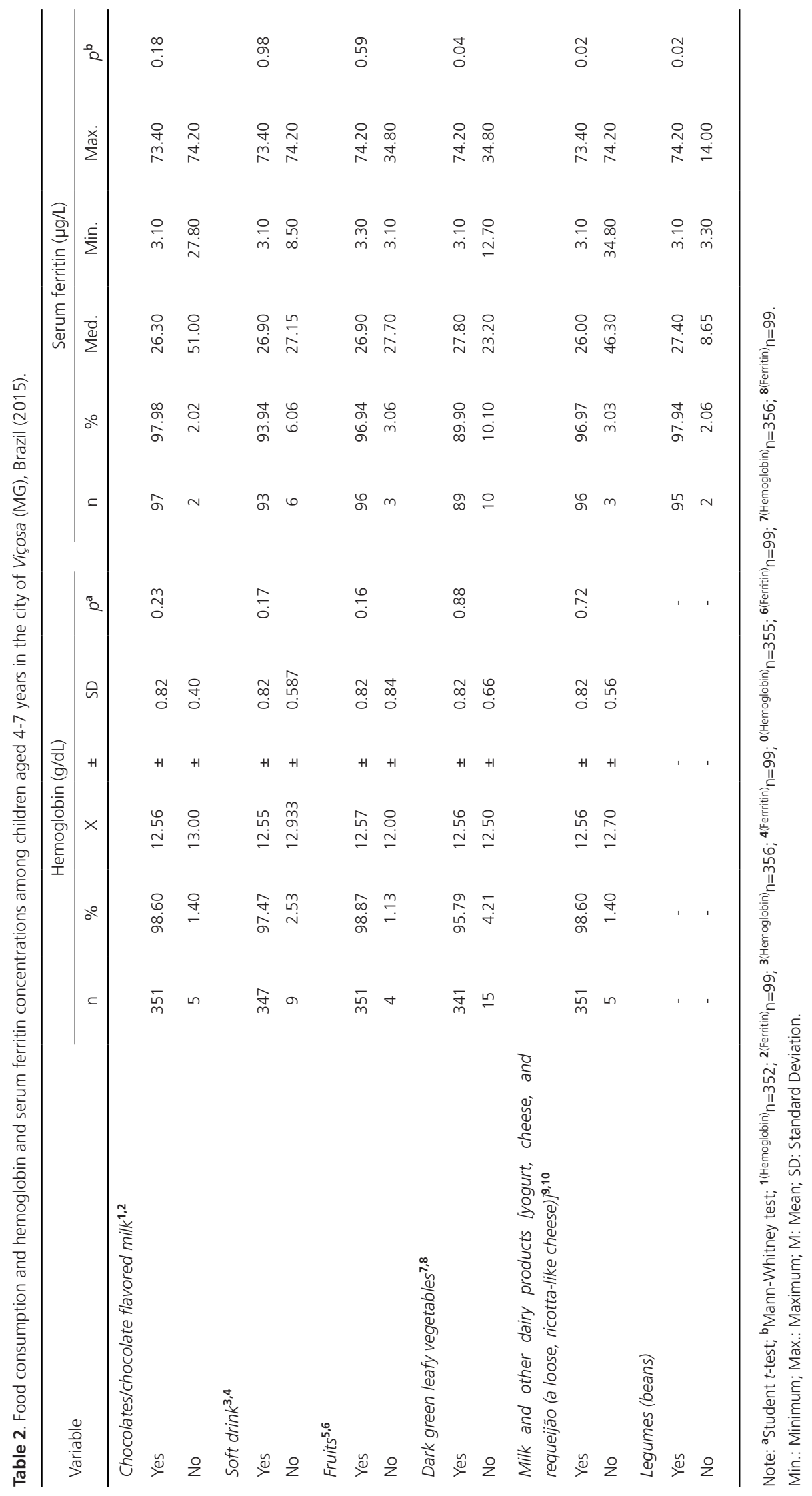


Table 3. Correlation of variables with hemoglobin and serum ferritin concentrations among children 4-7 years of age in the city of Viçosa (MG), Brazil (2015).

\begin{tabular}{|c|c|c|c|c|}
\hline \multirow{2}{*}{ Variables } & \multicolumn{2}{|c|}{ Hemoglobin (g/dL) } & \multicolumn{2}{|c|}{ Serum ferritin $(\mu \mathrm{g} / \mathrm{L})$} \\
\hline & $r$ & $p$-valor & $r$ & $p$-valor \\
\hline Current child weight & $0.19^{a}$ & $<0.001$ & $0.21^{\mathrm{a}}$ & 0.03 \\
\hline Current child height & $0.20^{\mathrm{b}}$ & $<0.001$ & $0.18^{\mathrm{a}}$ & 0.06 \\
\hline Child height-for-age (Z-score) & $0.15^{b}$ & $<0.001$ & $0.02^{\mathrm{a}}$ & 0.77 \\
\hline Current child age & $0.18^{\mathrm{a}}$ & $<0.001$ & $0.32^{\mathrm{a}}$ & $<0.001$ \\
\hline Current maternal age & $0.17^{\mathrm{a}}$ & $<0.001$ & $0.05^{\mathrm{a}}$ & 0.56 \\
\hline
\end{tabular}

Note: ${ }^{a} r=$ Spearman's correlation coefficient; ${ }^{\mathbf{b}} r=$ Pearson's correlation coefficient.

Table 4. Final multiple linear regression model for the factors associated with the iron nutritional status (hemoglobin and serum ferritin) among children 4-7 years of age in the city of Viçosa (MG), Brazil (2015).

\begin{tabular}{|c|c|c|c|c|c|c|c|}
\hline \multirow{2}{*}{ Variable } & \multicolumn{3}{|c|}{ Hemoglobin (g/dL) } & \multirow{2}{*}{ Variable } & \multicolumn{3}{|c|}{${ }^{*}$ Serum ferritin $(\mu \mathrm{g} / \mathrm{L})$} \\
\hline & $\beta$ & $95 \% \mathrm{Cl}$ & $p$-value & & $\beta$ & $95 \% \mathrm{Cl}$ & $p$-value \\
\hline Child age & 0.01 & $0.00-0.01$ & $<0.001$ & Child age & 0.04 & $0.02-0.07$ & $<0.001$ \\
\hline Maternal education & 0.03 & $0.00-0.05$ & 0.01 & $\begin{array}{l}\text { Consumption of } \\
\text { chocolates/chocolate } \\
\text { flavored milk }\end{array}$ & & & \\
\hline Height-for-age (Z-score) & 0.09 & $0.01-0.18$ & 0.02 & Yes & -2.32 & $-4.05-(-0.59)$ & $<0.001$ \\
\hline Marital status & & & & No & - & - & \\
\hline Married or domestic partnership & - & - & & & & & \\
\hline Single, separated, widow & -0.32 & $-0.11-(-0.52)$ & $<0.001$ & & & & \\
\hline
\end{tabular}

Note: $95 \% \mathrm{Cl}$ : 95\% Confidence interval; $\beta$ : Linear regression coefficient; "Square root.

According to the World Health Organization, anemia affects about 1,620 billion people worldwide, and the prevalence of iron deficiency is 2.5 times higher than that of anemia [2]. However, different proportion was found in the present study with similar prevalence of anemia and iron deficiency.

In this present study, determinants of iron nutritional status, investigated by measuring hemoglobin and serum ferritin concentrations, were analyzed using multiple linear regression models. There was a correlation between child age and hemoglobin and serum ferritin levels, leading to the conclusion that older child age is a protective factor for iron deficiency anemia since hemoglobin and serum ferritin concentrations were higher in older children. This finding can be explained by the variety of older children's food choices compared to that of younger children $[15,16]$.

With regard to anthropometric data, it was observed that in the final model heightfor-age Z-scores remained associated with hemoglobin levels. Thus, we presume that anemia and low height-for-age are related to inadequate breastfeeding practices, food and nutritional education, insufficient consumption of iron-rich foods, and the presence of infectious diseases in children [17].

In the analysis of the frequency of food consumption, chocolate and chocolate flavored milk remained associated with low ferritin levels in the final multiple linear regression model $(p<0.05)$. These foods are more frequently consumed by children, and they have anti- 
nutritional factors such as tannins which inhibit iron absorption [18].

It was also found that children who consumed milk before, during, or shortly after meals had lower serum ferritin values than those who did not have this habit $(p<0.05)$. Similar results were reported in another study [19]. The consumption of milk with salty meals has been related to the inhibitory effect on iron absorption due to the presence of calcium. Therefore, the WHO recommends that milk should not be consumed close to mealtime [2].

Children who consumed dark green leafy vegetables and legumes had higher ferritin values than those who did not consume these foods $(p<0.05)$. In a study investigating a program of nutritional education in schools aimed at reducing the prevalence of iron deficiency anemia in Venezuela, it was found that iron deficiency prevalence was higher among children who consumed less fruits and dark green leafy vegetables [20]. The reason is that dark green leafy vegetables and legumes (beans) are good sources of iron, and the consumption of these foods ensures improved iron nutritional status [18].

In a study [21] investigating socioeconomic and demographic determinants of anemia among children, it was found that low level of maternal education was associated with low hemoglobin levels; in the present study, maternal education remained associated with hemoglobin levels in the final multiple linear regression model. Parents' education can be considered as a socioeconomic factor associated with anemia [22]. Higher education level enhances the chances for employment, and, consequently, to more income, which results in increased access to food. Moreover, higher level of maternal knowledge seems to lead to the better children nutrition [23].

In a study [24] on anemia among preschool children, a public health problem, it was found a relationship between anemia and low income per capita. In the present study, it was found that children from households with per capita income less than or equal to $1 / 4$ of the minimum wage had lower hemoglobin levels, showing that lower per capita income is a risk factor for low concentrations of hemoglobin. This fact can be attributed to financial difficulty acquiring foods high in iron and early introduction of complementary foods, indicating food and nutritional insecurity.

In the present study, maternal marital status was associated with hemoglobin levels in the final multiple linear regression model, which is inconsistent with the findings of another study on the prevalence and determinants of anemia in children attending public daycare facilities in Belo Horizonte (MG) [25], in which there was association between anemia and marital status. Their results may be due to the greater financial difficulty acquiring iron-rich foods, less access to adequate health services, low household income, and poor sanitation conditions that can occur in household with single, separated, or widowed mothers and are less common in households with married mothers or those who have a domestic partner.

One limitation of the present study was the use of only two parameters (hemoglobin and serum ferritin) to diagnose iron nutritional status in children, which made it impossible to establish causal relationships.

\section{CONCLUSION}

The results obtained in the present study allow us to conclude that anemia among children 4 to 7 years is a public health problem in the city of Viçosa (MG), Brazil.

The factors associated with anemia were child age and nutritional status, maternal education, and maternal socio-demographic characteristics. Iron deficiency was associated with child age and dietary habits, which resulted in low iron intake or low iron absorption (low frequency of consumption iron-rich foods, habit of 
drinking milk close to mealtime, and consumption of chocolates and chocolate flavored milk).

The identification of these factors that are associated with the iron nutritional status indicates the need for intervention measures targeting children in this age group. These measures can be implemented through food and nutritional education by encouraging the consumption of iron-rich foods.

\section{CONTRIBUTORS}

HP ANDRÉ and SA VIEIRA participated in data collection, tabulation and discussion of the results and elaboration of the article. SCC FRANCESCHINI participated in the collection of data, tabulation and discussion of the results and elaboration of the article. SE PRIORE participated in the elaboration of experimental strategy, tabulation and discussion of the results and elaboration of the article. AQ RIBEIRO and HHM HERMSDORFF participated in the preparation of the project.

\section{REFERE N CES}

1. World Health Organization. Iron deficiency anaemia: Assessment, prevention, and control: A guide for program managers. Genebra: WHO; 2001.

2. World Health Organization. Haemoglobin concentrations for the diagnosis of anaemia and assessment of severity. Vitamin and mineral nutrition information system. Geneva: WHO; 2011.

3. World Health Organization. Growth reference 5-19 years. Genebra: WHO; 2007 [cited 2015 Oct 10]. Available from: http://who.org.int/growthref/ who2007

4. Zanin FHC, Correia DN, Lamounier JA, Carvalho MG, Fausto MA. Determinants of Iron Deficiency Anemia in a Cohort of Children Aged 6-71 Months Livingin the Northeast of Minas Gerais, Brazil. Plos One. 2015;10(10):704-10 https://doi. org/10.1371/journal.pone.0139555

5. Janus J, Moerschel SK. Evaluation of anemia in children. Am Fam Physician. 2010;81(12):1462-71.

6. Ministério da Saúde (Brasil). Pesquisa Nacional de Demografia e Saúde da Criança e da Mulher: relatório final. Brasília: Ministério da Saúde; 2008 [acesso 2009 maio 4]. Disponível em: www.saude. gov.br/pnds2006
7. Dias ACP, Szarfarc SC. Intervenção nutricional alternativa no controle da anemia em crianças e mães. Rev Espaço Saúde. 2013;14(1):7-13.

8. Instituto Brasileiro de Geografia e Estatísticas. Cidades: censo 2010. Brasília: IBGE; 2010.

9. World Health Organization. Worldwide prevalence of anemia 1993-2005: WHO Global Data Base on Anemia. Geneva: WHO; 2008.

10. Soh P, Ferguson EL, Mckenzie JE, Homs MY, Gibson RS. Iron deficiency and risk factors for lower iron stores in 6-24 month-old New-Zealandes. Eur J Clin Nutr. 2004;58(1):71-9.

11. World Health Organization. WHO AnthroPlus for personal computers. Manual: Software for assessing growth of the world's children and adolescents. Geneva: WHO; 2009.

12. Ministério da Saúde (Brasil). Vigilância Alimentar e Nutricional (SISVAN). Classificação do estado nutricional. Brasília: Ministério da Saúde; 2009.

13. Pacheco JP, Schedler FLS, Hermes L, Molz P, Franke SIR. Prevalência de anemia e fatores associados em crianças de 6 a 24 meses matriculadas na rede pública de Venâncio Aires. Rev Jovens Pesquisadores. 2013;3(1):179-90.

14. Male C, Persson LA, Freeman V, Guerra A, Vat Hoff MA. Prevalence of iron deficiency in 12 moold infants from 11 European areas and influence of dietary factors on iron status. Acta Pediatr. 2001;90(2):492-8.

15. Leal LP, Batista Filho ML, Osório MM. Temporal trends and anaemia associated factors in 6- to 59-month-old children in Northeast Brazil. Public Health Nutr. 2012;15(9):1645-52.

16. Netto MP, Rocha DS, Franceschini SCC, Lamounier JA. Fatores associados à anemia em lactentes nascidos a termo e sem baixo peso. Rev Assoc Med Bras. 2011;57(5):550-8.

17. Instituto Brasileiro de Geografia e Estatísticas. Pesquisa de orçamentos familiares 2008-2009: antropometria e estado nutricional de crianças, adolescentes e adultos no Brasil. Rio de Janeiro: IBGE; 2010.

18. Sociedade Brasileira de Pediatria. Anemia ferropriva em lactentes: revisão com foco em prevenção. São Paulo: Sociedade Brasileira de Pediatria; 2012.

19. Netto MP, Priore SE, Sant'Ana HMP, Peluzio MCG, Sabarense CM, Silva DG, et al. Prevalência e fatores associados à anemia e deficiência de ferro em crianças de 18 a 24 meses. Arch Latinoam Nutr. 2006;56(3):229-36.

20. Carvajal Z, Leets I, Puche R, Jiminez ML, Casal MN, Patino E. A Program of nutritional education in schools reduced the prevalence of iron deficiency 
in students. Clin Study. 2011;16(3):203-8. https:// doi.org/10.1155/2011/284050

21. Goswmai S, Das K. Socio-economic and demographic determinants of childhood anemia. J Pediatr. 2015;91(5):417-77.

22. Correa MM, Arpini LSB, Ferreira DM. Estado nutricional e prevalência de anemia em crianças menores de 36 meses. Rev Bras Promo Saúde. 2014;27(1):109-16.

23. Leal LP, Osório MM. Fatores associados à ocorrência de anemia em crianças menores de seis anos: uma revisão sistemática dos estudos populacionais. Rev Bras Saúde Matern Infant. 2010;10(4):417-39.
24. Oliveira TSC, Lamounier JA, Alves CRL, Capanema FD, Rocha DS, Silva MC. Anemia entre pré-escolares: um problema de saúde pública em Belo Horizonte, Brasil. Ciênc Saúde Coletiva. 2014;19(1):59-66.

25. Rocha DS, Capanema FD, Netto MP, Franceschini SCC, Lamounier JA. Prevalência e fatores determinantes da anemia em crianças assistidas em creches de Belo Horizonte - MG. Rev Bras Epidemiol. 2012;15(3):675-84.

Received: May 20, 2016

Final version: September 21, 2016

Approved: December 13, 2016 
